(C) 1991 Journals of Reproduction \& Fertility Ltd

\title{
Immunoreactive adrenocorticotrophin is present in the ovary and in particular the oocyte of several mammalian species
}

\author{
R. A. Jacobs*, J. Oosterhuis*, D. G. Porter†, D. K. Lobb†, A. A. Yuzpe $\ddagger$ \\ and J. R. G. Challis* \\ *Lawson Research Institute, St. Joseph's Health Centre, MRC Group in Fetal and \\ Neonatal Development, University of Western Ontario, London, Ontario, Canada N6 A 4V2; \\ $\dagger$ Department of Biomedical Sciences, University of Guelph, Ontario Veterinary College, Guelph, \\ Ontario, Canada N1G 2W1; and $\ddagger$ Department of Obstetrics and Gynaecology, University Hospital, \\ London, Ontario, Canada N6A 5 A5
}

\begin{abstract}
Summary. Proopiomelanocorticotrophin (POMC)-derived peptides have been identified in both male and female reproductive systems. However, there have been few reports of $\mathrm{ACTH}$, the major biologically active POMC product, in the mammalian ovary. We sought evidence for the presence and localization of immunoreactive (ir)-ACTH in ovaries from sheep, humans, cows, pigs, rats and cats using immunohistochemical techniques. Tissue sections were stained with diaminobenzidine following incubation with a primary antibody raised against $\mathrm{ACTH}_{1-24}$. There was positive staining for ACTH in cells scattered throughout the interstitium of ovaries from all species examined. Immunoreactive ACTH was observed in the oocytes of ovaries from humans, cows, pigs, pregnant and non-pregnant sheep, but not from cats or rats. Positive staining of oocytes was associated with all tertiary and secondary follicles, and some primary follicles. There was no apparent difference in the pattern of staining between pregnant and non-pregnant sheep. Staining for ir-ACTH was absent in ovaries from fetal sheep. We conclude that ir-ACTH is present in ovarian tissue, and in particular the oocyte, from several species of mammal. The presence of ir-ACTH within the oocyte is dependent on species and stage of follicular maturation.
\end{abstract}

Keywords: oocyte; ovary; adrenocorticotrophin; immunocytochemistry

\section{Introduction}

Proopiomelanocorticotrophin (POMC)-derived peptides have been identified by radioimmunoassay and immunocytochemistry in several extrapituitary tissues including the placenta (Rees $e t$ al., 1975; Liotta et al., 1977; Krieger, 1982), gut and pancreas (Bruni et al., 1979; Feurle et al., 1980), testis (Sharp et al., 1980; Tsong et al., 1982b) and ovary (Lim et al., 1983; Shaha et al., 1984). In the rat ovary, $\beta$-endorphin and $\alpha$-melanocyte stimulating hormone ( $\alpha-\mathrm{MSH})$ have been localized in the corpora lutea (Bardin et al., 1987), while in the ovary of the mouse these peptides have been identified also in granulosa and interstitial cells (Shaha et al., 1984). Furthermore, $\beta$-endorphin and ACTH have been reported to be present in the granulosa cells and corpora lutea of the nonpregnant sheep (Lim et al. 1983). This would suggest that there are differences in the localization of POMC-derived peptides between species.

In the rat, POMC mRNA has been detected in ovarian tissue from pregnant and non-pregnant animals (Chen et al., 1986), suggesting that the ovary is the source of POMC products identified by immunohistochemistry. Expression of POMC mRNA in the ovary increases in rats treated with 
androgens and gonadotrophins (Chen et al., 1986; Melner et al., 1986), suggesting modulation of the ovarian synthesis of POMC-derived peptides by these agents.

Despite the reports of POMC-derived peptides in ovarian tissue, cellular localization of adrenocorticotrophin, the major biologically active post-translational product of POMC, has not been investigated in freshly obtained ovarian tissue. Therefore, we used immunohistochemistry to seek the presence and localization of immunoreactive ACTH in the ovary of several species in order to determine the species specificity of its localization.

\section{Materials and Methods}

Ovaries were collected from non-pregnant sheep ( $N=3$, obtained from a local abattoir), cows $(N=2$, obtained from Ontario Veterinary College, $\mathrm{OVC})$, pigs $(\mathrm{N}=4, \mathrm{OVC})$ and cats $(\mathrm{N}=2, \mathrm{OVC})$. In addition, tissues were obtained from non-pregnant $(\mathrm{N}=4)$ and pregnant $(\mathrm{N}=6)$ rats after euthanasia with chloroform. Ovaries were also obtained from pregnant sheep $(\mathrm{N}=6)$ and their fetuses during the last third of pregnancy. Ovaries were obtained from 9 premenopausal women who suffered menstrual disorders and underwent total abdominal hysterectomy. Ovaries were fixed in Bouin's solution (pH 7.4) for $24 \mathrm{~h}$, then washed in several changes of $70 \%$ ethanol. Tissues were embedded in paraffin wax and sectioned at a thickness of $5 \mu \mathrm{m}$. The sections were incubated for 20 min with $10 \%$ goat serum and endogenous peroxidase activity was blocked with $0.3 \%$ hydrogen peroxide. Staining was performed using an avidinbiotin-peroxidase procedure (Vectastain, Vector Laboratories, Burlington, CA, USA). Sections were incubated with a polyclonal primary antibody raised in rabbits against $\mathrm{ACTH}_{1-24}$ (1:1000 or 1:2000 dilution; Dako Laboratories, Santa Barbara, CA, USA) for $48 \mathrm{~h}$ at $4^{\circ} \mathrm{C}$ in an humidified chamber. The sections were washed, incubated with an avidin-IgG complex (anti-rabbit, 1:500) and stained using 0.05\% (w/v) diaminobenzidine and $0.03 \%(\mathrm{v} / \mathrm{v})$ hydrogen peroxide. Tissues were counterstained with Curazzi's haematoxylin and mounted.

The specificity of immunostaining was determined by pre-incubating the primary antibody with $1 \mu \mathrm{mol}$ of ACTH $_{1-39}$, ACTH $_{1-24}$, ACTH $_{1-18}, \mathrm{ACTH}_{1-13}(\alpha-\mathrm{MSH}), \mathrm{ACTH}_{11-24}, \mathrm{ACTH}_{18-39}$ (CLIP) or $\beta$-endorphin/ lipotropin $_{61-91}$ overnight at $4^{\circ} \mathrm{C}$. Peptide purity was determined by reverse phase HPLC on a Bondapak C18 column (Waters Assoc., Milford, MA, USA) as described previously (Challis et al., 1989). The specificity of staining for ACTH was further evaluated using a primary antibody raised in rabbits to ovine corticotrophin-releasing hormone (CRH). The specificity of the CRH antibody has been reported previously (Brooks et al., 1989). In other negative controls the primary antibody was omitted or replaced with $10 \%$ goat serum. A section of adult sheep pituitary was included with each set of ovarian sections and always stained positive for ACTH.

Table 1. The pattern of staining for ir-ACTH in ovaries from the sheep, cow, pig, human, cat and rat

\begin{tabular}{lllccccc}
\hline Species & No. & $\begin{array}{c}\text { Primary } \\
\text { follicles* }\end{array}$ & $\begin{array}{c}\text { Secondary } \\
\text { follicles* }\end{array}$ & $\begin{array}{c}\text { Tertiary } \\
\text { follicles* }\end{array}$ & Interstitium $\dagger$ & $\begin{array}{c}\text { Corpus } \\
\text { Theca } \dagger\end{array}$ \\
\hline Sheep, fetal & 8 & $0 / 1450$ & $0 / 0$ & $0 / 8$ & $0 / 8$ & $0 / 8$ & $0 / 8$ \\
Sheep, adult luteum $^{*}$ & 9 & $6 / 91$ & $8 / 8$ & $7 / 7$ & $7 / 9$ & $5 / 9$ & $0 / 9$ \\
Cow & 2 & $0 / 1$ & $3 / 3$ & $4 / 4$ & $2 / 2$ & $2 / 2$ & $0 / 2$ \\
Pig & 4 & $3 / 13$ & $14 / 14$ & $4 / 4$ & $3 / 4$ & $0 / 4$ & $0 / 4$ \\
Human§ & $9(1)$ & $2 / 5$ & $1 / 1$ & $1 / 1$ & $7 / 9$ & $3 / 10$ & $0 / 3$ \\
Cat & 2 & $0 / 7$ & $0 / 2$ & $0 / 2$ & $2 / 2$ & $0 / 3$ & $0 / 2$ \\
Rat; & 10 & $0 / 17$ & $0 / 16$ & $0 / 18$ & $4 / 10$ & $2 / 10$ & $0 / 10$ \\
\hline
\end{tabular}

*Values represent the number of follicles in which oocytes stained positive for $\mathrm{ACTH}$ as a fraction of the total number of follicles in which oocytes were present.

†Values represent the number of animals or women in which positive staining for ACTH was observed in the respective tissues as a fraction of the number of tissues from animals or women that were examined.

$\ddagger$ Values are pooled from pregnant and non-pregnant animals.

$\S$ Nine ovaries from human patients were examined, but only 1 ovary had secondary or tertiary follicles in which an oocyte was present.

\section{Results}

Immunoreactive (ir) ACTH staining in ovarian structures is summarized in Table 1, and examples are given in Figs 1 and 2. Oocytes in ovaries from pregnant (Fig. 1a) and non-pregnant sheep and from humans (Fig. 2e), cows (Fig. 2a) and pigs (Fig. 2f) stained positive for ir-ACTH. There was 

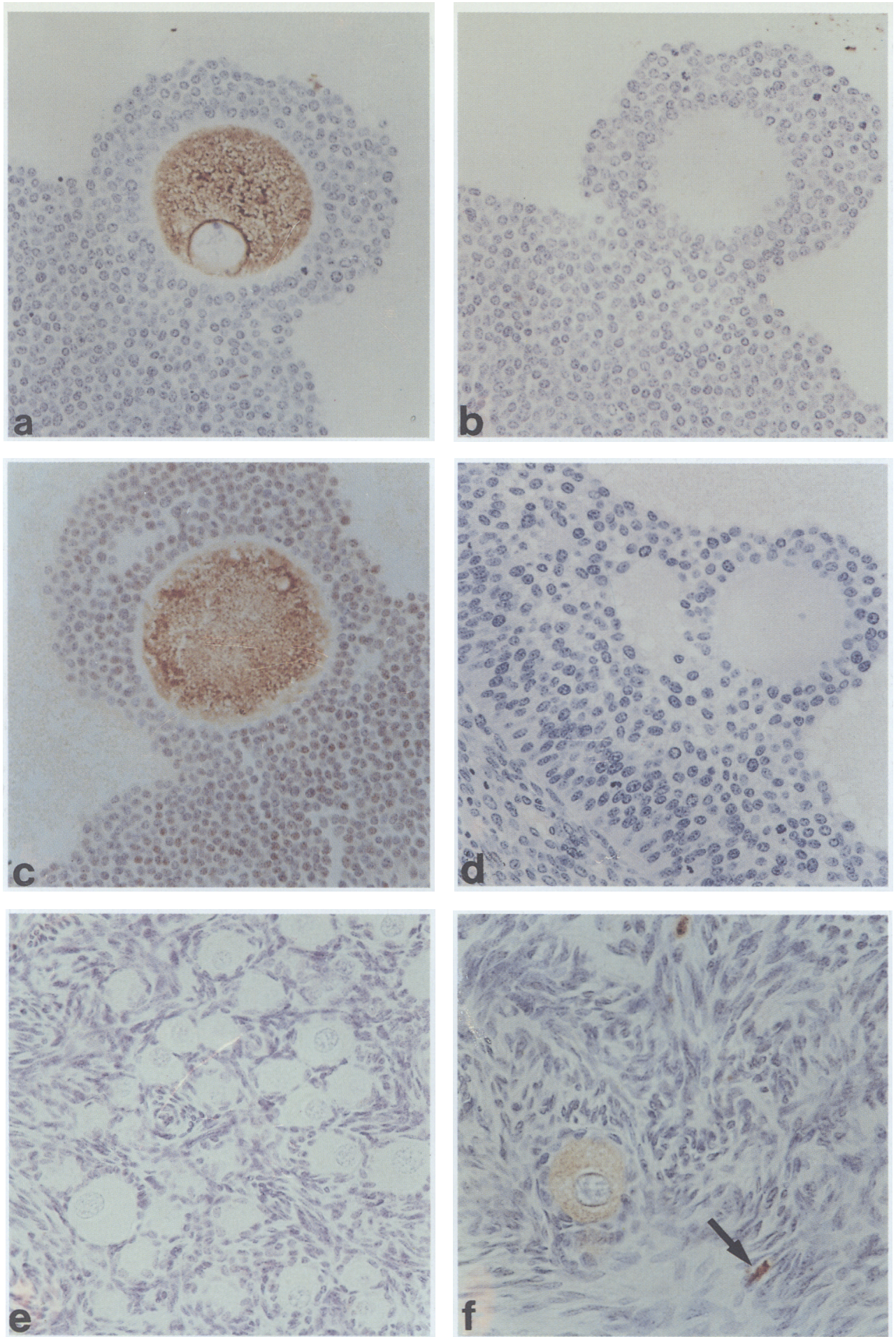

Fig. 1. ACTH staining in sheep ovarian tissue. (a) Oocyte stained with primary antibody to $\mathrm{ACTH}_{1-24}$; (b) absence of staining in the oocyte after preabsorbing the primary antibody with $1 \mu \mathrm{mol} \mathrm{ACTH} \mathrm{Al}_{18-39}$; (c) persistent oocyte staining after preabsorbing the primary antibody with $1 \mu \mathrm{mol} \mathrm{ACTH}{ }_{1-17}$; (d) lack of positive staining with a primary antibody to ovine $\mathrm{CRH}$; (e) lack of staining to $\mathrm{ACTH}_{1-39}$ in primordial follicles and other cell types in the fetal ovary; (f) positive staining seen in some primary follicles in adult sheep ovary and thecal cells (arrow). Magnification $\times 100$. 

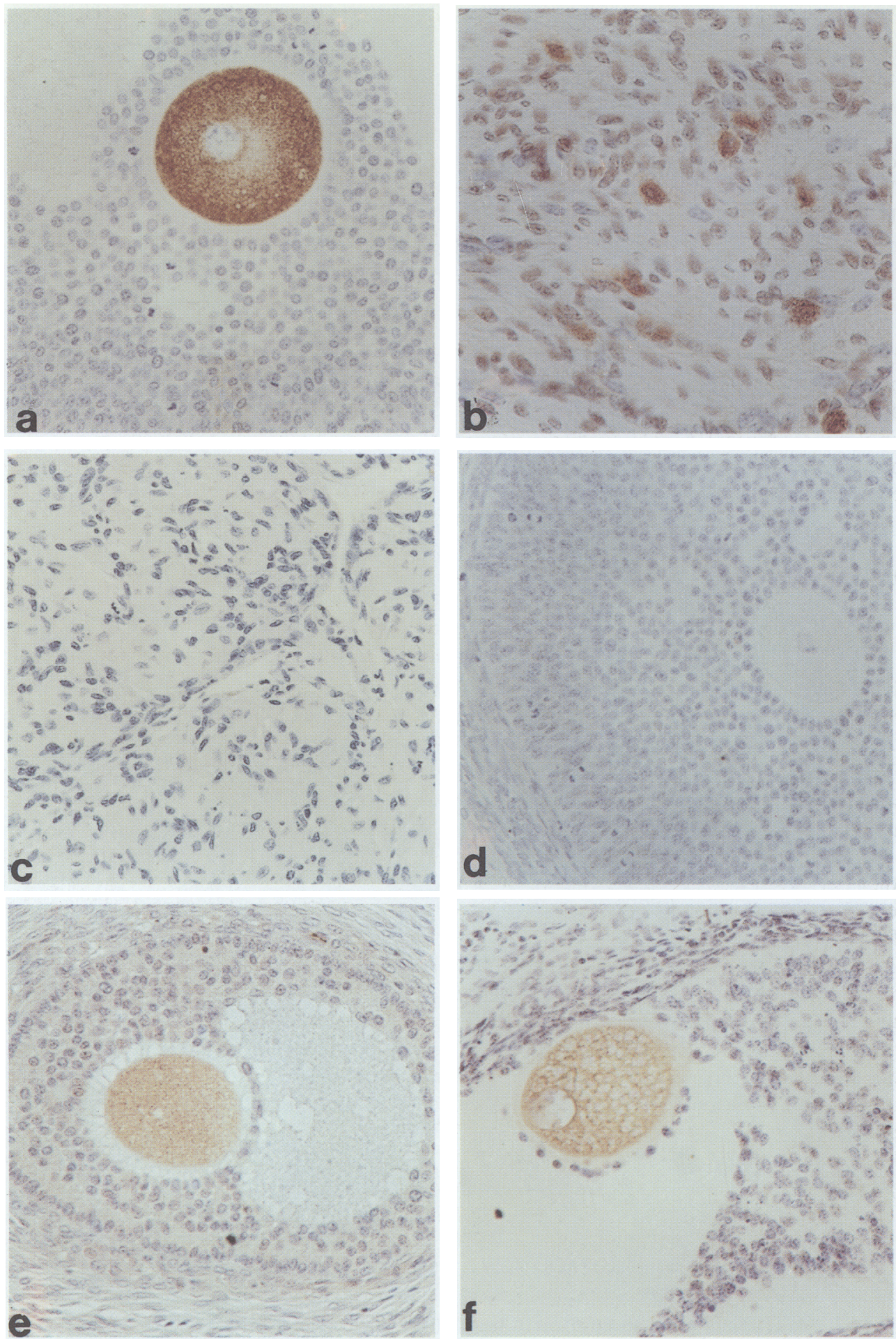

Fig. 2. ACTH staining in cow, rat, human and pig ovary. (a) Positive ir-ACTH staining in the oocyte from a tertiary follicle of the cow: (b) ir-ACTH in scattered stromal cells in the ovary of the cow; (c) lack of ir-ACTH staining in the cow corpus luteum; (d) lack of positive ir-ACTH staining in a pre-antral follicle from the adult rat; (e) positive ir-ACTH staining in the oocyte of the human ovary; (f) positive ir-ACTH staining in the oocyte of the pig ovary. Magnification $\times 100$. 
no staining in the oocytes of the ovary from pregnant (Fig. 2d) or non-pregnant rat, or cat (Table 1). In ovaries from the human, sheep, cow and pig, staining was present in oocytes of all tertiary and secondary follicles that were examined. Staining was present in the oocyte of some primary follicles (Fig. 1f), although this was not a consistent finding. In the fetal ovary ir-ACTH was not localized to the oocyte above non-specific background staining (Fig. 1e).

There was positive cytoplasmic staining for ir-ACTH in scattered clusters of interstitial cells of ovaries from all species studied (e.g. cow, Fig. 2b). This was independent of positive or negative staining in the oocytes. There was very sparse staining for ir-ACTH in the cytoplasm of isolated thecal cells of ovaries from women, pregnant and non-pregnant sheep, cow and pig, but ir-ACTH was not detectable in corpora lutea of any of the sections examined (e.g. cow, Fig. 2c).

Immunoabsorption of the primary antibody with ACTH fragments of different sizes before staining indicates the specificity of the antibody. Staining was not abolished after pre-absorption of the antibody with $\beta$-endorphin, or with $\mathrm{ACTH}_{1-17}$ (Fig. Ic) and $\mathrm{ACTH}_{1-13}$, suggesting that there was not an $\mathrm{N}$-terminal ACTH antigenic site. Staining was blocked after pre-absorption of the primary antibody with $\mathrm{ACTH}_{1-24}, \mathrm{ACTH}_{18-39}$ (Fig. 1b), or $\mathrm{ACTH}_{1-39}$. Since the antibody was raised against $A C \mathrm{TH}_{1-24}$ there is not likely to be an antigenic site between amino acids 25 and 39, and the recognition site is probably against the mid-sequence of $\mathrm{ACTH}$, between amino acids 18 and 24 . Staining was absent when the primary antibody was replaced with goat serum or with an antibody to ovine CRH (Fig. 1d).

\section{Discussion}

We have identified the presence of ir-ACTH in the oocyte and interstitium of ovaries from several mammalian species. While the presence of ir-ACTH in the oocyte is species-specific, positive staining for ir-ACTH was found in interstitial cells of all species studied.

POMC-related peptides have not been reported previously in mammalian oocytes. This may be because oocytes are not commonly present in ovarian sections. In our experience, only a small number of sections from all species examined (except rat) contained oocytes. In addition, few laboratories have investigated the localization of $\mathrm{ACTH}_{1-39}$ in the ovary. It is not yet known whether POMC-related peptides (such as $\beta$-endorphin) that have been investigated by others are present in the oocytes of any mammals. The antibody used in the present study cross-reacts with $\mathrm{ACTH}_{1-39}$ and CLIP (ACTH ${ }_{18-39}$ ), but would not detect the presence of $\beta$-endorphin or $\alpha$-MSH.

Ovaries from the rat and cat did not exhibit positive staining for ACTH in oocytes, but oocyte from the human, sheep, pig and cow did show the appearance of ir-ACTH. The presence of positive staining in the cat and rat interstitium indicates that the lack of staining in the oocyte is not due to failure of our antibody to recognize ACTH from these species. It is interesting to speculate on the reasons for the species differences in ACTH staining in the oocyte. One possibility is that the oocyte of the rat and cat may utilize POMC-derived peptides other than ACTH or CLIP which would not have been detected in the present study.

The presence of POMC-derived peptides in ovarian tissue has been reported previously for sheep and mice (Lim et al., 1983; Shaha et al., 1984), but localization was confined to granulosa cells and to corpora lutea. We did not observe staining for ACTH/CLIP in the corpora lutea of ovaries from any species examined. This difference in the pattern of staining between the present study and that of Shaha et al. (1984) is probably due to either a difference in the molecular form of ACTH-like peptides between sheep and mice or to a difference in the specificity of the primary antibodies. In our study, the antibody was specific for the mid-sequence of $\mathrm{ACTH}_{1-39}$. In the study by Shaha et al. (1984) the antibodies did not cross-react significantly with ACTH $_{1-39}$. This would suggest that there is an alteration in the post-translational processing of ACTH and perhaps POMC generally in cells of the corpora lutea. Alternatively, the corpus luteum may take up POMC-derived peptides other than $\mathrm{ACTH}_{1-39}$. In addition, we did not detect the presence of ir-ACTH in the corpus luteum any of the species studied. 
Lim et al. (1983) used immunofluorescence to show the presence of ir-ACTH in follicular cells and corpora lutea taken from non-pregnant sheep and cultured for $48-72 \mathrm{~h}$. They do not report the specificity of the antibody used in the immunofluorescence procedure. We did not detect ir-ACTH in granulosa cells from any species studied, including the sheep. One explanation of this may be differences in the specificity of the antibody used. Another explanation could be that the culture conditions used by Lim et al. (1983) induced differentiation of the follicular cells and an alteration in the processing of POMC by these cells. Lim et al. (1983) further report that acid extracts of ovarian tissue (follicular cells and corpora lutea) from non-pregnant sheep contained ir-ACTH measured by radioimmunoassay. The antibody used in the assays is reported to be specific for all or part of the amino acid sequence 18-24 of the ACTH molecule. However, they also state that the ACTH antibody did not cross-react with CLIP which contains the amino acid sequence 18-24 within its ACTH-like structure of 18-39 amino acids. This contradiction makes interpretation of the results of Lim et al. (1983) difficult in the context of the present study.

The sites of POMC synthesis in the ovary are yet to be determined. It is possible that the oocyte does not contain the gene for POMC, but rather the oocyte takes up ACTH/CLIP from adjacent cells or POMC is taken up by the oocyte from adjacent tissue and is enzymically cleaved to produce an ACTH-like peptide. ACTH and other POMC-derived peptides are known to be present in the follicular fluid of humans, sheep and pigs (Lim et al., 1983; Facchinetti et al., 1988; Steinleitner et al., 1989). This fluid may be a source of POMC-derived peptides for the oocyte or these peptides could be produced by the oocyte and secreted into follicular fluid. However, it is not yet known whether there is any correlation between the presence of ACTH in the oocyte and in the follicular fluid.

Sections of ovaries from fetal sheep did not immunostain for ACTH. Consistent with this, Shaha et al. (1984) were unable to demonstrate positive staining for another POMC-derived peptide, $\beta$-endorphin, in the ovaries of prenatal and neonatal mice. Treatment with PMSG induced the appearance of immunostainable $\beta$-endorphin in neonatal mice (Shaha et al., 1984) and increased the expression of ovarian POMC mRNA in adult cycling rats (Chen et al., 1986). Furthermore, pregnancy results in both an increase in the ovarian concentration of immunoreactive $\beta$-endorphin (Shaha et al., 1984; Autelitano et al., 1986) and in the amount of POMC mRNA (Chen et al., 1986). This is consistent with variations in the concentration of ovarian $\beta$-endorphin and ACTH during the oestrous cycle (Lim et al., 1983; Lolait et al., 1985). The present study was not controlled for variations during the oestrous cycle. However, ir-ACTH was present in oocytes in all tertiary and secondary follicles, but only in some primary follicles in human, sheep, cow and pig ovaries. These observations suggest that, while gonadotrophins may play a role in the production and release of POMC-derived peptides, there are probably other factors which influence either uptake or synthesis of ir-ACTH by oocytes as follicles mature from primary to secondary development.

There is no information available regarding the role of ACTH-like peptides in the oocyte or in interstitial cells. It is unlikely that POMC-related peptides, derived from the ovary, have an endocrine function, and it is more likely that they act in a paracrine fashion. $O$ (1990) has demonstrated that $\beta$-endorphin inhibited breakdown of the germinal vesicle in cultured rat oocytes. This effect was reversed by addition of naloxone, implying that it is mediated through opioid receptors, and suggesting that $\beta$-endorphin has an inhibitory role on meiosis in the rat ovary. Testicular derived POMC peptides (Tsong et al., 1982a, b; Chen et al., 1986; Cheng et al., 1987; Lacaze-Masmonteil et al., 1987) may promote mitosis of Sertoli cells and steroidogenesis in Leydig cells (Bardin et al., 1987). The possibility remains that ACTH and other POMC-related peptides may have similar functions within the ovary.

This work was supported in part by the Canadian Medical Research Council (Group Grant in Fetal and Neonatal Health and Development, J.R.G.C.), and by a studentship from the Lawson Research Institute (J.O.). D.G.P. and D.K.L. acknowledge the support of NSERC (OGP 0036690) and the University of Guelph Research Enhancement Fund. 


\section{References}

Autelitano, D.M., Lolait, S.J., Smith, A.I. \& Funder, J.W. (1986) Pregnancy-associated changes in ovarian immunoreactive $\beta$-endorphin in rats. $J$. Endocr. 108, 343-350.

Bardin, C.W., Chen, C-L.C., Morris, P.L., Gerandai, I., Boitani, C., Liotta, A.S., Margioris, A. \& Krieger, D.T. (1987) Proopiomelanocortin-derived peptides in testis, ovary, and tissues of reproduction. Recent Prog. Horm. Res. 43, 1-28.

Brooks, A.N., Power, L.A., Jones, S.A., Yang, K.P. \& Challis, J.R.G. (1989) Controls of corticotrophinreleasing factor output by hypothalamic tissue from fetal sheep in vitro. J. Endocr. 122, 15-22.

Bruni, J.F., Watkins, W.B. \& Yen, S.S.C. (1979) BEndorphin in the human pancreas. J. clin. Endocr. Metab. 9, 651-699.

Challis, J.R.G., Fraher, L., Oosterhuis, J., White, S.E. \& Bocking, A.D. (1989) Fetal and maternal endocrine responses to prolonged reductions in uterine blood flow in pregnant sheep. Am. J. Obstet. Gynecol. 160, 926-932.

Chen, C-L., Chang, C-C., Krieger, D.T. \& Bardin, C.W. (1986) Expression and regulation of proopiomelanocortin-like gene in the ovary and placenta: comparison with the rat testis. Endocrinology 118, 2382-2389.

Cheng, M.C., Clements, J.A., Smith, A.I., Lolait, S.J. \& Funder, J.W. (1987) N-acetyl endorphin in rat spermatogonia and primary spermatocytes. J. clin. Invest. $75,832-835$.

Facchinetti, F., Storchi, A.R., Petraglia, F., Volpe, A. \& Genazzani, A.R. (1988) Expression of proopiomelanocortin-related peptides in human follicular fluid. Peptides 9, 1089-1092.

Fuerle, G.E., Weber, V. \& Helmstaedter, V. (1980) Corticotropin-like substances in human gastric antrum and pancreas. Biochem. Biophys. Res. Commun. 95, $1656-1662$.

Krieger, D.T. (1982) Placenta as a source of 'brain' and 'pituitary' hormones. Biol. Reprod. 26, 55-71.

Lacaze-Masmonteil, T., deKeyzer, Y., Luton, J-P., Kahn, A. \& Bertagna, X. (1987) Characterization of proopiomelanocortin transcripts in human nonpituitary tissues. Proc. natn. Acad. Sci. USA 84, 7261-7265.

Lim, A.T., Lolait, S., Barlow, J.W., Wai, S.U., Zois, I., Toh, B.H. \& Funder, J.W. (1983) Immunoreactive $\beta$-endorphin in sheep ovary. Endocrinology 101, 1552-1558.
Liotta, A., Osathanondh, R., Ryan, K.J. \& Krieger, D.T. (1977) Presence of corticotropin in human placenta: demonstration of in vitro synthesis. Endocrinology 101, 1552-1558.

Lolait, S.J., Autelitano, D., Lim, A.T.W., Smith, A.I., Toh, B.H. \& Funder, J.W. (1985) Ovarian immunoreactive $\beta$-endorphin and estrous cycle in the rat. Endocrinology 117, 161-168.

Melner, M.H., Young, S.L., Czerweic, F.S., Lyn, D., Puett, D., Roberts, J.L. \& Koos, R.D. (1986) The regulation of granulosa cell proopiomelanocortin messenger ribonucleic acid by androgens and gonadotropins. Endocrinology 119, 2082-2085.

O, W-S. (1990) The effect of $\beta$-endorphin on rat oocyte maturation in vitro. Molec. cell. Endocrinol. 68, 181-185.

Rees, L.H., Burke, C.W., Chard, T., Evans, S.W. \& Letchworth, A.T. (1975) Possible placental origin of ACTH in normal human pregnancy. Nature, Lond. 254, 620-622.

Shaha, C., Margioris, A., Liotta, A.S., Krieger, D.T. \& Bardin, C.W. (1984) Demonstration of immunoreactive $\beta$-endorphin and $\gamma_{3}$-melanocyte stimulating hormone-related peptides in the ovaries of neonatal, cyclic, and pregnant mice. Endocrinology 115, 378384.

Sharp, B., Pekary, A.E., Meyer, N.V. \& Hershman, J.M. (1980) $\beta$-Endorphin in male rat reproductive organs. Biochem. Biophys. Res. Communm. 95, 618-623.

Steinleitner, A., Stanczyk, F.Z., Paulson, R.J. \& Lobo, R.A. (1989) Characterization of proopiomelanocortin (POMC) peptides in porcine and human follicular fluid. Proc. Soc. Gynecol. Invest. 36th Ann. Meet., San Diego, Abstr. 587.

Tsong, S.D., Phillips, D., Halmi, N., Krieger, D.T. \& Bardin, C.W. (1982a) $\beta$-Endorphin is present in the male reproductive tract of five species. Biol. Reprod. 27, 755-764.

Tsong, S.D., Phillips, D., Halmi, N., Liotta, A.S., Margioris, A., Bardin, C.W. \& Krieger, D.T. (1982b) ACTH and $\beta$-endorphin-related peptides are present in multiple sites in the reproductive tract of the male rat. Endocrinology 110, 2204-2206.

Received 17 May 1990 